\title{
A Theoretical Perspective on the Requirements of the 21st Century for Teachers' Curriculum as Praxis
}

\author{
Marisa M.C. Verster, Elsa Mentz, Charlene du Toit-Brits \\ North-West University (Potchefstroom), South Africa
}

\begin{abstract}
The focus of this article is to discuss the requirements of the 21st century for teachers' curriculum as praxis. It is evident from the literature that the 21st century is quite different from the previous centuries, in that learners have to be prepared for ongoing, unpredictable and rapid changes that also influence the knowledge that are relevant for the 21st century. The ongoing dynamics influencing education also implicate the curriculum and the requirements for teachers regarding the ways in which they could be teaching to prepare learners for the 21st century. Educational and curriculum changes are philosophically underpinned, leading to changes in the requirements of the 21st century for teachers' curriculum as praxis. In this article, we argue that if teachers could adapt their curriculum practices to become more praxis-oriented, this would assist them in utilizing the requirements of the 21st century effectively for their curriculum as praxis.
\end{abstract}

\section{Introduction}

The 21st century differs considerably from previous centuries, which had multiple influences on the world, specifically on education, because of the ongoing, rapid changes experienced in the 21st century [1], [2], [3], [4]. These influences also initiated changes in the requirements of the 21st century for teachers, because learners need to be prepared for the constant, dynamic changes occurring in the world [5], [2], [3], [4]. Accordingly, Trilling and Fadel [6] contend that the necessary skills of the 21st century are learning and innovation skills, digital literacy skills, career and life skills, including initiative and self-direction. Some other requirements for teachers of the 21st century are for them to:

i. be mediators of constant change;

ii. have continuous self-development, with the ability to learn on one's own;

iii. facilitate interactive teaching-learning experiences;

iv. be self-directed;

v. put knowledge into the real-life context of the 21st-century learning; vi. define learning as a lifelong process;

vii. be culturally competent;

viii. be inventive;

ix. have emotional awareness;

$\mathrm{x}$. develop entrepreneurial skills;

xi. be able to think critically;

xii. be able to solve problems (in any context);

xiii. display flexibility, adaptability, productivity, accountability, leadership and responsibility; and

xiv. become 21st-century learners by learning from inquiry, design and collaboration.

The world of the 21st century could be explained by the development that occurred from the major schools of philosophy and how these influenced educational philosophies [2], [7], [8] and curriculum philosophies [9], [10]. The philosophical developments also provide a basis for why curriculum as praxis is needed for education in the 21st century. Therefore, the rationale for this article is two-fold. In the first instance, the purpose is to discuss the requirements of the 21st century for teachers' curriculum as praxis. Secondly, it is to explain why curriculum as praxis could assist teachers to utilize and meet 21st-century requirements effectively for their curriculum as praxis.

This article includes an overview of the philosophical underpinning of curriculum. The philosophical influences on distinctive curriculum domains will be explained in order to reach an understanding of curriculum as praxis. Finally, the requirements of the 21st century for teachers' curriculum as praxis will be emphasized. In the next section, the philosophical underpinning of curriculum is discussed to illustrate the development that guided curriculum changes towards the 21st century.

\section{Philosophical underpinning of curriculum}

While exploring the philosophical underpinning of curriculum, we realized how the major philosophies (idealism, realism, pragmatism, existentialism and postmodernism) have influenced the educational philosophies (perennialism, essentialism, progressivism, reconstructionism and 
critical theory), as is extensively discussed by Gutek [8]. These major philosophies also influenced the curriculum philosophies (scholarly academic, social efficiency, learner-centred and social reconstruction), as is discussed by Schiro [10]. Referring to Figure 1, these philosophical developments can be divided into two distinctively influential eras, namely the traditional era and the contemporary era [11], [2].

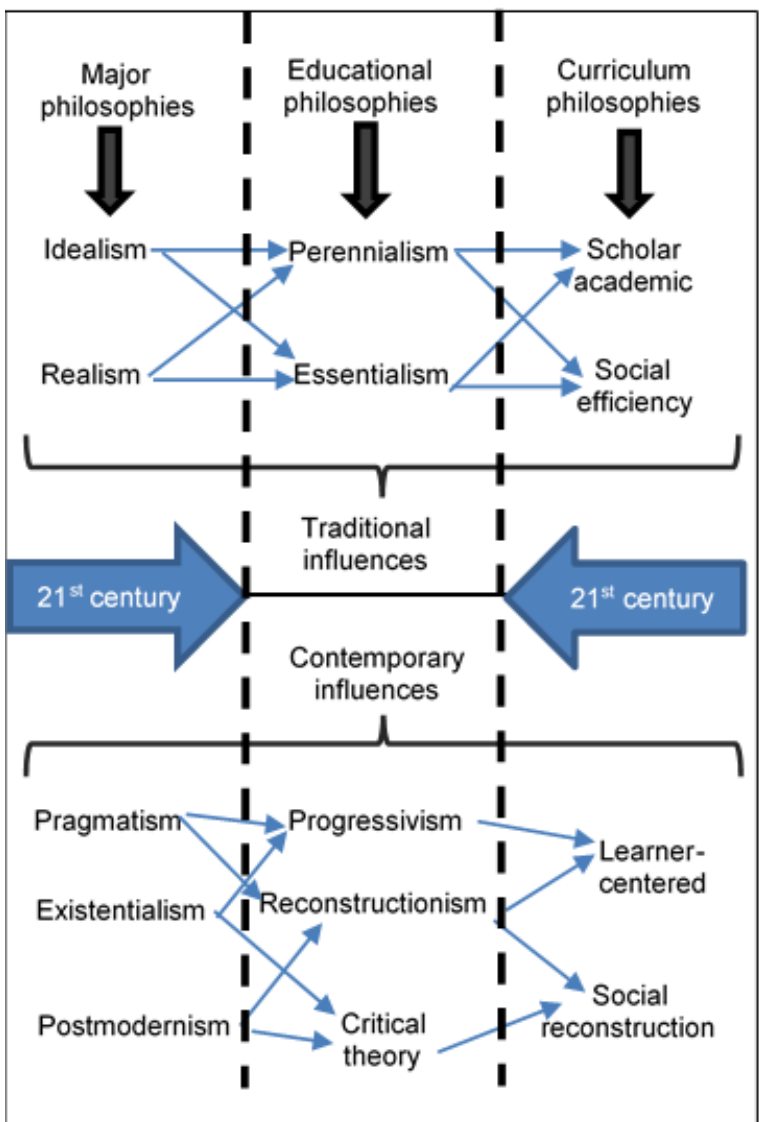

Figure 1. Philosophical underpinning of curriculum

Traditionally viewed, idealism and realism initiated perennialism and essentialism [8], which influenced the scholar academic and social efficiency philosophy of curriculum, as described by Schiro [10]. Traditional philosophical thoughts were about learning and acquiring the universal truths and values. These truths and values were universal only because of the unchanging world in which people lived. Education was aimed at teaching learners these utopian, universal ideas, and teachers were expected to be the knowledgeable people who could teach learners these ideas, which were compiled in a very prescriptive and predetermined curriculum.

The contemporary era developed more recently, constituting the major philosophies of pragmatism, existentialism and postmodernism, which influenced the educational philosophies of progressivism, reconstructionism and critical theory [8]. The curriculum philosophies, which derived from the contemporary philosophies, are the learner-centered philosophy and the social reconstruction philosophy [10]. The main idea of this philosophical era started by viewing knowledge construction pragmatically, through problem solving and by using the scientific method. The learners' experiences and experiential learning became vital, as opposed to rote learning, lesson recitation and textbook authority. In the contemporary views, the curriculum should be interdisciplinary and the teacher should act as a facilitator guiding the learners in creative and collaborative ways in order to develop vital skills to function successfully in the 21st century. Similar to the pragmatists, reconstructivists also believe that education should be a social construction, rather than being merely academic, through creating a new, more democratic, more humanitarian and more reasonable society [8], [12]. Therefore, reconstructionist education should reconstruct, reform and renew the existing society [8]. The curriculum should include reform strategies to keep up with the social, economic and political influences on education, because society is continually changing and so should the curriculum [2].

It is important to notice that changes in educational philosophies have occurred over several years, originating from the major philosophies. These changes also caused changes in curriculum philosophies, which had, and still are having, divergent influences on schools and their curricula. Therefore, the arrows in Figure 1 indicate the influences of the major philosophies (left) on the educational philosophies (middle) and subsequently on the curriculum philosophies (right). The major educational and curriculum philosophies also developed respectively from older (top) to more recent (bottom) philosophical thoughts, as indicated by the bolded arrows. For the context of this inquiry, it was important to deduce the applicable philosophical underpinning for education in the 21st century to be most effective, as indicated by the prominent distinction from the traditional philosophies to the more contemporary philosophies (indicated by the 21st-century arrows). From the discussion below and as indicated in Figure 1, it is clear that the contemporary philosophies are more appropriate than the traditional philosophies for education in the 21st century, because the traditional philosophies focused on finding and educating about one global truth to be true for all people. With the dynamic knowledge growth of the 21st century, one universal or global truth cannot be adhered to.

\section{Curriculum domains}

The prominent domains of the curriculum (design, development, implementation) are discussed next, to demonstrate the relevance of how these domains were influenced by the philosophical underpinnings as discussed above. The influences from these 
philosophical developments on curriculum to develop toward curriculum as praxis, are then discussed.

\subsection{Curriculum designs}

For the purpose of this article, curriculum design is understood as the way(s) in which different components of the curriculum are structured in order to stimulate optimal learning opportunities for learners. Referring to Figure 2, the curriculum designs, which Ornstein and Hunkins [2] and [13] explained, are the subject-centered designs, the learner-centered designs, the problem-centered designs within schooling in the conservative tradition, schooling in the progressive tradition and schooling in the radical tradition respectively.

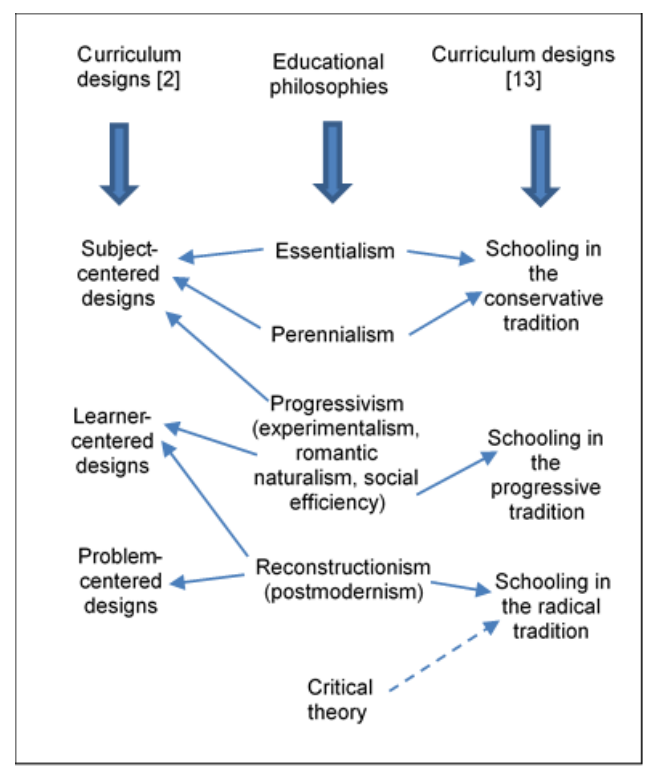

Figure 2. Edcational philosophical underpinning of curriculum design

The traditional educational philosophies of perennialism and essentialism underpinned the curriculum designs, which were subject-centered within schooling in the conservative tradition. Although progressivism started to break away to more contemporary thoughts, it still showed some relevance of content-driven subjects. Progressivism, however, also underpinned more learner-centered designs within schooling in the progressive tradition. Schooling from this era is not appropriate for teaching in the $21^{\text {st }}$ century anymore. Reconstructionism, in a similar sense, underpins learner-centered designs as well as problem-centered designs within schooling in the radical tradition. Naturally then, progressivism, reconstructionism and critical theory could enhance learning in the $21^{\text {st }}$ century, because these philosophical underpinnings support $21^{\text {st }}$-century skills, e.g. innovation, flexibility, adaptability and initiative. Therefore, learner-centered designs within schooling in the progressive tradition and problem-centered designs within schooling in the radical tradition could support $21^{\text {st-century learning. }}$

From Figure 2, it is important to deduce that if we (as role players in the field of education) are aiming towards moving beyond the major traditional philosophies that underpinned traditional education philosophies and curriculum philosophies, we need to continue developing in the direction of more contemporary philosophical underpinnings, especially with regard to the way(s) in which the intended curriculum is designed.

\subsection{Curriculum development}

In agreement with Carl [14], curriculum development constitutes the continuing, dynamic process of change in the curriculum from design to evaluation and further to redesign and re-evaluation and so forth. In curriculum development, there are also two approaches, namely the technical-scientific and the nontechnical-non-scientific approaches [2].

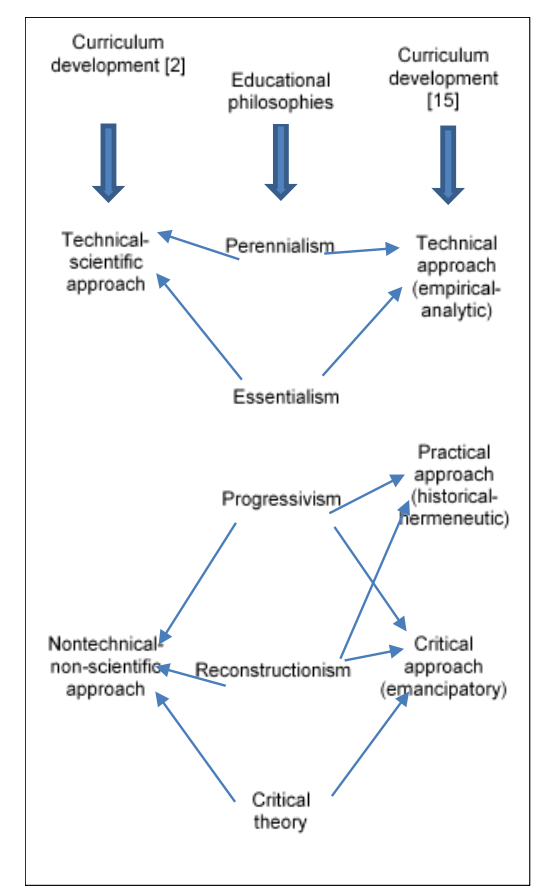

Figure 3. Educational philosophical underpinning of curriculum development

Frame [15] maintains that theoretical underpinnings of the curriculum cannot be separated from managing curriculum development and change; therefore, she advocates three approaches to curriculum development, namely the technical, practical and critical approaches. Referring to Figure 3 , the technical-scientific approach to curriculum development concurs with the educational philosophies of perennialism and essentialism, which are not sufficient for education in the 21st century. Supporting this thought, literature and theories of 
curriculum show development far beyond the technical, product-oriented approach [16], [17], [15]. The technical-scientific approach resonates with the traditional era of education, whereas the nontechnical-non-scientific approach resonates with the more contemporary era of education. The nontechnical-non-scientific approach to curriculum development concurs with the educational philosophies of progressivism, reconstructionism and critical theory. These philosophical underpinnings of the nontechnical-non-scientific approach to curriculum development, as discussed previously, could better support education in the 21st century, because it suggests practical and critical orientations towards the way(s) in which a curriculum develops.

\subsection{Curriculum implementation}

Regarding curriculum implementation and how it has changed over many years, Carl [14] argues that teachers play a prominent role in successfully implementing a curriculum, but teachers should also feel empowered in the process (as in the contemporary view of education), rather than being forced regarding specific ways of implementing a curriculum (as in the traditional view of education).

Aoki [18] wrote extensively about two perspectives regarding curriculum implementation: curriculum implementation as instrumental action and curriculum implementation as situational praxis. Shawer [19] and Hlebowitsh [13] refer to Snyder, Bolin and Zumwalt [20] who distinguished three perspectives on curriculum implementation: the fidelity approach, mutual adaptation and curriculum enactment.

Curriculum implementation as instrumental action relates well to the fidelity approach. Aoki [18] explains that according to this perspective, the effectiveness of curriculum implementation depends on how well communiqués are transferred from a higher authority to teachers. Hlebowitsh [13] confirms that within the fidelity approach, exact transmission occurs between the planned curriculum and the implemented experience; therefore, the curriculum is a "script for teachers to follow", sometimes even including instructional prescriptions. Shawer [19] adds that external experts determine what teachers should teach; therefore, he names this approach curriculum transmission. The problem with viewing implementation as instrumental action is that it is not a true reflection of real-world experiences [18].

Curriculum implementation as situational praxis - in this article curriculum as praxis - relates well with the two approaches of Snyder, Bolin and Zumwalt [20], by being mutual adaptation and curriculum enactment. Mutual adaptation is the notion of curriculum development where an interplay between the design of a curriculum and the practice thereof occurs [13]. Snyder et al. [20] (in [19]) explain that mutual adaptation means that adjustments could be made to a curriculum as discussed by the curriculum developers and the teachers who apply it in different classroom contexts. Through conversations, the teachers and external developers introduce adaptations that are necessary for matching the curriculum to local contexts, and for Shawer [19], this constitutes curriculum development.

Curriculum enactment prioritizes the occurrences within a classroom, where teachers are given the independence to create relevant experiences for the learners they teach [13]. Curriculum knowledge is thus not a prescribed product anymore, but rather an ongoing construction of the enacted experiences created by the teacher and learners [20] (in [19]). The enacted curriculum becomes a process where both the teacher and the learners [20] (in [19]) jointly create and individually experience education. Thus, the teachers become the designers and implementers of the curriculum [13]; therefore, Shawer [19] named this curriculum making.

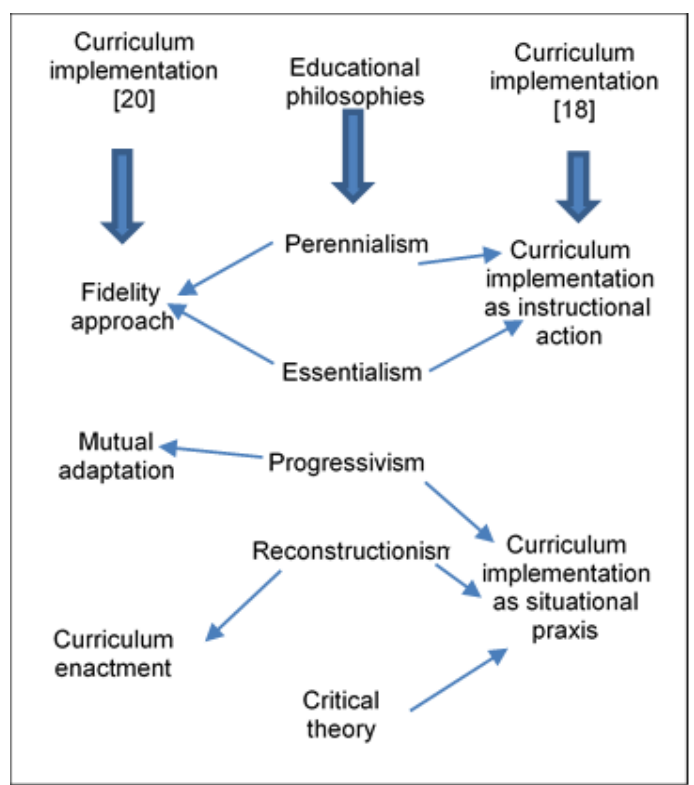

Figure 4. Educational philosophical underpinning of curriculum implementation

From the discussion above and referring to Figure 4 , it is clear that perennialism and essentialism underpin curriculum implementation as instrumental action within the fidelity approach. Curriculum implementation as situational praxis, constituting the approaches of mutual adaptation and curriculum enactment, is underpinned by progressivism, reconstructionism and, to some extent, critical theory. Referring to Figure 4, it is clear that the educational philosophies that underpin curriculum implementation perspectives, could also be separated by more traditional philosophies versus more contemporary philosophies. Our argument is thus 
that curriculum implementation as situational praxis or curriculum as praxis will best support education in the $21^{\text {st }}$ century, especially when considering the philosophical developments and influences that underpin the three prominent curriculum domains of design, development and implementation.

\section{Curriculum as praxis}

Drawing from Schwandt's [21] explanation of practical wisdom or praxis, practical wisdom could be realized where people live and act together, learning from and influencing each other. Practical wisdom or praxis resonates with the contemporary views on education, as well as curriculum implementation as situational praxis. Practical wisdom differs from the firm control and fabrication of the productive activity [21], which resonates with the older, traditional technical views on education.

To regard the curriculum as a form of praxis, Grundy [22] elaborates on the following elements:

- $\quad$ action and reflection, where the curriculum itself develops through the dynamic interaction of action and reflection, rather than being a set of plans to implement;

- $\quad$ praxis takes place in the real world, and the curriculum cannot be constructed without implementation in real situations with real learners;

- praxis operates in the world of interaction, socially and culturally, meaning that the curriculum cannot only be about learning 'things', but should be a social act, a dialogical relationship between the teacher and the learners;

- the world of praxis is constructed and knowledge is a social construction, because groups of learners become active participants while constructing their own knowledge; and

- praxis assumes a process of meaningmaking; therefore, critical orientations to knowledge become pivotal.

These elements of curriculum as praxis resonate with the expectations of education in the contemporary era, where education should focus on being learner-centered and should be oriented towards reconstructing relevant and applicable knowledge for the $21^{\text {st }}$ century (see Table 1 ).

In strengthening this argument, curriculum as praxis further relates to the emancipatory interest of the practical activity. Habermas (1972) in Grundy [22] clarifies that emancipation refers to a state of autonomy, rather than to libertinism. Therefore, emancipation acknowledges autonomy and responsibility, where self-reflection becomes an imperative [22]. Therefore, the emancipatory interest focuses on "the ability of individuals and groups to take control of their own lives in autonomous and responsible ways” [22]. Grundy [22] and Makrakis and Kostoulas-Makrakis [23] continue that the emancipatory curriculum constitutes a continuous mutual relationship between self-reflection and action, including the facilitator as well as the learners (practical activity). Planning, acting and evaluating a curriculum thus become active processes of integration [22]. Freire [24] explains that education is constantly changing through praxis, specifically reflection and action, which truly transforms people's reality. Transforming people's reality is "the source of knowledge and creation" [24], or knowledge construction. This idea of the emancipatory interest developed from the idea of the practical interest [22]. The practical interest is practice-oriented, while knowledge is also produced through meaning-making to be able to take the correct action within the applicable environment [22]. The practical curriculum design relates much to Stenhouse's [25] research, where the process of making meaning of the world occurs in interaction between the facilitator and the learners [22], [26]. Curriculum components, such as objectives, content and resources can be assembled in subtle ways to generate a coherent curriculum [27], but the state of autonomy, responsibility and self-reflection (emancipatory interest) is lacking. Therefore, curriculum as praxis seems more appropriate and applicable than the productive activity for assisting teachers to utilize the requirements of the $21^{\text {st }}$ century effectively for their own curriculum as praxis.

Grundy [22] further explains that the emancipatory interest of curriculum as praxis engages the learner, where the learner is not a passive receiver of knowledge, but rather "an active creator of knowledge along with the teacher”. Being a passive receiver of knowledge is very traditional and technical, whereas a learner who becomes an active creator alongside a facilitator, is much more contemporary, learner- and problem-centered, nontechnical and empowering. Hence, curriculum as praxis could assist teachers in understanding the $21^{\text {st }}$ century requirements more comprehensively, because while teachers were previously viewed as the main holders of knowledge, they could now be required to learn alongside the learners to be lifelong learners, as listed in the introduction. Previously, knowledge was seen as universal and constant, and although these knowledge constructs are not all irrelevant now, new knowledge should be constructed to cope in the $21^{\text {st }}$ century.

Viewing praxis in Schwandt's (practical activity) [21] and Grundy's [22] way explains why curriculum as praxis could be vital for teachers, especially when teaching in the $21^{\text {st }}$ century with the constant changes that people are experiencing. 


\section{Requirements of the $21^{\text {st }}$ century for teachers' curriculum as praxis}

Table 1 consolidates the requirements for teachers of the traditional and contemporary philosophical periods with teachers' requirements for curriculum as praxis.

Table 1. Consolidated teachers' requirements in relation to teachers' curriculum as praxis

\begin{tabular}{|c|c|c|}
\hline $\begin{array}{c}\text { Teachers' } \\
\text { requirements: } \\
\text { Traditional } \\
\text { philosophical } \\
\text { period } \\
\text { = productive } \\
\text { activity }\end{array}$ & $\begin{array}{l}\text { Teachers' } \\
\text { requirements: } \\
\text { Contemporary } \\
\text { philosophical } \\
\text { period } \\
=\text { practical activity }\end{array}$ & $\begin{array}{c}\text { Teachers' } \\
\text { requirements: } \\
\text { Curriculum as } \\
\text { praxis }\end{array}$ \\
\hline $\begin{array}{l}\text { Model and } \\
\text { mature } \\
\text { representative of } \\
\text { specific culture; } \\
\text { Find and teach } \\
\text { universal truth; } \\
\text { The teacher is the } \\
\text { possessor of } \\
\text { subject-matter, } \\
\text { knowledge and } \\
\text { instructional } \\
\text { skills; } \\
\text { The teacher is the } \\
\text { developer of } \\
\text { rationality and the } \\
\text { intellect of } \\
\text { learners through } \\
\text { great works of the } \\
\text { past; } \\
\text { The teacher is an } \\
\text { expert in his or } \\
\text { her subject field; } \\
\text { The teacher is the } \\
\text { transmitter of } \\
\text { truths and } \\
\text { previously } \\
\text { accumulated } \\
\text { knowledge; } \\
\text { Therefore, } \\
\text { curriculum } \\
\text { transmission }\end{array}$ & $\begin{array}{l}\text { Guide, resource } \\
\text { and facilitator; } \\
\text { Engage learners } \\
\text { actively; respect } \\
\text { learners' individual } \\
\text { freedom of choice, } \\
\text { open-minded, } \\
\text { reflective; } \\
\text { Include variety of } \\
\text { narratives } \\
\text { (oppressors and } \\
\text { oppressed); } \\
\text { Wary of pre- } \\
\text { existing } \\
\text { curriculum; } \\
\text { Intellectual, critical, } \\
\text { changeable, } \\
\text { insightful, } \\
\text { inspiring; } \\
\text { The teacher is the } \\
\text { facilitator that } \\
\text { guides the } \\
\text { learners through } \\
\text { problem solving; } \\
\text { Flexible, creative, } \\
\text { collaborative; } \\
\text { Use learners' life } \\
\text { stories as a } \\
\text { starting point; } \\
\text { Focus on learners' } \\
\text { interests; } \\
\text { The teacher is a } \\
\text { researcher } \\
\text { Therefore, } \\
\text { curriculum } \\
\text { development and } \\
\text { curriculum making }\end{array}$ & $\begin{array}{l}\text { Interacting } \\
\text { dynamically } \\
\text { between action and } \\
\text { reflection; } \\
\text { Within real-world } \\
\text { contexts; } \\
\text { Having interaction } \\
\text { between the social } \\
\text { and cultural world; } \\
\text { Constructing } \\
\text { knowledge through } \\
\text { meaning-making } \\
\text { The teacher is: } \\
\text { - reflective; } \\
\text { - active; } \\
\text { - creative; and } \\
\text { - focuses on } \\
\text { contextually and } \\
\text { socially constructing } \\
\text { knowledge }\end{array}$ \\
\hline
\end{tabular}

Here it becomes even clearer that the requirements for teachers' curriculum as praxis relates to the requirements of the contemporary philosophical period.

Table 2. Consolidated teachers' requirements in relation to the $21^{\text {st }}$ century and teachers' curriculum as praxis

\begin{tabular}{|c|c|c|}
\hline $\begin{array}{l}\text { Teachers' } \\
\text { requirements: } \\
\text { contemporary } \\
\text { philosophical } \\
\text { period }\end{array}$ & $\begin{array}{l}\text { Teachers' } \\
\text { requirements: } \\
21^{\text {st }} \text { century }\end{array}$ & $\begin{array}{l}\text { Teachers' } \\
\text { requirements: } \\
\text { curriculum as } \\
\text { praxis }\end{array}$ \\
\hline $\begin{array}{l}\text { Guide, resource } \\
\text { and facilitator; } \\
\text { Engage learners } \\
\text { actively; respect } \\
\text { learners' } \\
\text { individual } \\
\text { freedom of } \\
\text { choice, open- } \\
\text { minded, } \\
\text { reflective; } \\
\text { The teachers } \\
\text { include a variety } \\
\text { of narratives } \\
\text { (oppressors and } \\
\text { oppressed); } \\
\text { Wary of pre- } \\
\text { existing } \\
\text { curriculum; } \\
\text { The teacher is } \\
\text { intellectual, } \\
\text { critical, } \\
\text { changeable, } \\
\text { insightful, } \\
\text { inspiring; } \\
\text { The teacher is a } \\
\text { facilitator guiding } \\
\text { learners through } \\
\text { problem solving; } \\
\text { Flexible, creative, } \\
\text { collaborative; } \\
\text { Use learners' life } \\
\text { stories as a } \\
\text { starting point; } \\
\text { Focus on } \\
\text { learners' } \\
\text { interests; } \\
\text { The teacher is a } \\
\text { researcher } \\
\text { Therefore, } \\
\text { curriculum } \\
\text { development and } \\
\text { curriculum } \\
\text { making }\end{array}$ & 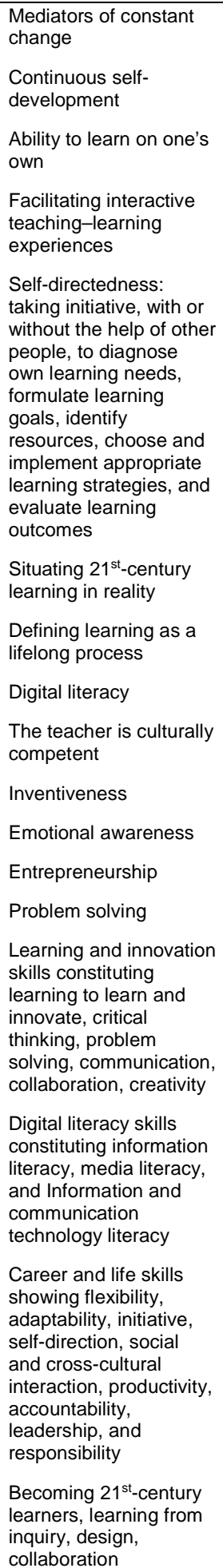 & $\begin{array}{l}\text { Interacting } \\
\text { dynamically } \\
\text { between action and } \\
\text { reflection; } \\
\text { Within real-world } \\
\text { contexts; } \\
\text { Showing interaction } \\
\text { between the social } \\
\text { and cultural world; } \\
\text { Constructing } \\
\text { knowledge through } \\
\text { meaning-making } \\
\text { The teacher is: } \\
\text { - reflective; } \\
\text { - active; } \\
\text { - creative; and } \\
\text { - focuses on } \\
\text { contextually and } \\
\text { socially } \\
\text { constructing } \\
\text { knowledge }\end{array}$ \\
\hline
\end{tabular}

From Table 1, it was already clear that the contemporary philosophical requirements for teachers resonate with the requirements for teachers from a curriculum as praxis perspective. In Table 2, 
further similarities between the requirements for teachers from the contemporary philosophical views and from the $21^{\text {st }}$ century and with curriculum as praxis are reflected.

\section{Conclusion}

In conclusion, we highlighted the need for teachers to adapt their curriculum practices to become more praxis-oriented to be able to prepare learners for the 21st century. The largest influence regarding these changes stemmed from philosophical developments, which also explain the relevance of teachers' own curriculum as praxis to progress. Theoretically, teachers who orient the functioning of their curriculum practices towards praxis, should be able to adapt towards the requirements of the 21st century.

\section{References}

[1] H. Janks, "Globalisation, Diversity, and Education: A South African perspective", The Educational Forum, 78(1), 2014, pp. 8-25.

[2] A.C. Ornstein, and F.P. Hunkins, Curriculum: Foundations, Principles and Issues, Pearson, Boston, 2013.

[3] T.M. Yek, and D. Penney, "Curriculum as Praxis: Ensuring Quality Technical Education in Singapore for the 21st Century", Education Policy Analysis Archives, 14(26), 2006, pp. 1-31.

[4] J.M. Esteve, "The Transformation of the Teachers' Role at the End of the Twentieth Century: New Challenges for the Future”, Educational Review, 52(2), 2000, pp. 197207.

[5] P.E. Bernhardt, "21st Century Learning: Professional Development in Practice”, The Qualitative Report, 20(1), 2015, pp. 1-19. Retrieved from http://www.nova.edu/ssss/QR/QR20/1/bernhardt1.pdf

[6] B. Trilling, and C. Fadel, 21st Century Skills: Learning for Life in our Times, Wiley, San Francisco, 2009.

[7] A.C. Ornstein, E.F. Pajak, and S.B. Ornstein, Contemporary Issues in Curriculum, Pearson, Boston, 2011.

[8] G.L. Gutek, New Perspectives on Philosophy and Education, Pearson, Boston, 2009.

[9] I. Marulcu, and C. Akbiyik, "Curriculum Ideologies: Re-Exploring Prospective Teachers' Perspectives”, International Journal of Humanities and Social Sciences, 4(5), 2014, pp. 200-206.

[10] M.S. Schiro, Curriculum Theory: Conflicting Visions, and Enduring Concerns, Sage, Los Angeles, 2013.
[11] F. Saçli Uzunöz, "The Philosophical Dispositions of Pre-service Teachers and Teacher Educators”, Educational Research and Reviews, 11(1), 2016, pp. 30-36.

[12] C. Tan, "Philosophical Perspectives on Education", in C. Tan, B. Wong, J.S.M. Chua, and T. Kang, eds., Critical Perspectives on Education: An Introduction, Prentice Hall, Singapore, 2006, pp. 21-40.

[13] P.S. Hlebowitsh, Designing the School Curriculum, Pearson, Boston, 2005.

[14] A.E. Carl, Teacher Empowerment through Curriculum Development: Theory into Practice, 4th ed., Juta, Cape Town, 2012.

[15] J. Frame, "Theorising Curriculum", in M. Coleman, M. Graham-Jolly, and D. Middlewood, eds., Managing Schools in South Africa: Managing the Curriculum in South African Schools, Commonwealth Secretariat, London, 2003, pp. 17-34.

[16] C. Booyse, and E. du Plessis, Curriculum Studies: Development, Interpretation, Plan and Practice, 2nd ed., Van Schaik, Pretoria, 2014.

[17] U. Hoadley, and J. Jansen, Curriculum: Organising Knowledge for the Classroom, 3rd ed., Oxford, Cape Town, 2012.

[18] T.T. Aoki, "Curriculum Implementation as Instrumental Action and as Situational Praxis", 1983, in W.F. Pinar, and R.L. Irwin, eds., Curriculum in a New Key: A Collected Works of Ted T Aoki. Lawrence Erlbaum, London, 2005, pp. 111-124.

[19] S.F. Shawer, "Classroom-level Teacher Professional Development and Satisfaction: Teachers Learn in the Context of Classroom-level Curriculum Development”, Professional Development in Education, 36(4), 2010, pp. 597-620.

[20] J. Snyder, F. Bolin, and K. Zumwalt, "Curriculum Implementation”, in P.W. Jackson, ed., Handbook of Research on Curriculum, Macmillan, New York, 1992, pp. 402-435.

[21] T.A. Schwandt, The Sage Dictionary of Qualitative Inquiry, Library of Congress Cataloging-in-publication Data, Los Angeles, 2007.

[22] S. Grundy, Curriculum: Product or Praxis, The Falmer Press, Philadelphia, 1987.

[23] T.P. Makrakis, and N. Kostoulas-Makrakis, "Bridging the Qualitative-quantitative Divide: Experiences from Conducting a Mixed Methods Evaluation in the RUCAS Programme”, Evaluation and Program Planning, 54, 2016, pp. 144-151.

[24] P. Freire, Pedagogy of the Oppressed, Continuum, New York, 1970.

[25] L. Stenhouse, An Introduction to Curriculum Research and Development, Heinemann, London, 1975. 
[26] T.N. Phan, M. Lupton, and J.J. Watters, "Understanding of the Higher Education Curriculum in Vietnam", Higher Education Research and Development, 35(6), 2016, pp. 1256-1268.

[27] C. Cornbleth, "Curriculum in and out of Context", Journal of Curriculum and Supervision, 3(2), 1988, pp. 8596. 